\title{
Neural Crest and Ectodermal Cells Intermix in the Nasal Placode to Give Rise to GnRH-1 Neurons, Sensory Neurons, and Olfactory Ensheathing Cells
}

\author{
Paolo Emanuele Forni, ${ }^{1}$ Carol Taylor-Burds, ${ }^{1}$ Vida Senkus Melvin, ${ }^{2}$ Taylor Williams, ${ }^{2}$ and Susan Wray ${ }^{1}$ \\ ${ }^{1}$ Cellular and Developmental Neurobiology Section, National Institute of Neurological Disorders and Stroke, National Institutes of Health, Bethesda, \\ Maryland 20892, and 2Departments of Craniofacial Biology and Cell and Developmental Biology, University of Colorado Denver, Aurora, Colorado 12801
}

The origin of GnRH-1 cells and olfactory ensheathing cells has been controversial. Genetic Cre-lox lineage tracing of the neural crest (NC) versus ectodermal contribution to the developing nasal placode was performed using two complementary mouse models, the NC-specific Wnt1Cre mouse line and an ectodermal-specific Crect mouse line. Using these lines we prove that the NC give rise to the olfactory ensheathing cells and subpopulations of GnRH-1 neurons, olfactory and vomeronasal cells. These data demonstrate that Schwann cells and olfactory ensheathing cells share a common developmental origin. Furthermore, the results indicate that certain conditions that impact olfaction and sexual development, such as Kallmann syndrome, may be in part neurocristopathies.

\section{Introduction}

Clarifying the developmental lineage of specific cell populations is fundamental to understanding syndromic diseases and to unravel the molecular etiology and relationship between various phenotypic outcomes. The nasal placodes are defined as ectodermally derived tissue thickenings that arise from the anterior end of the neural plate. Starting from embryonic day 10.5 (E10.5) in mouse, the nasal placodes invaginate and give rise to cell types including GnRH-1 neurons that migrate to the brain, olfactory sensory neurons (OSNs) that project to the brain (Wray et al., 1989) and olfactory ensheathing cells (OECs) that provide essential growth and guidance for OSN axons (Su and He, 2010).

GnRH-1 neurons are a population of cells with a key role in sexual development and behavior in vertebrates (Boehm et al., 2005; Wray, 2010). GnRH-1 neurons migrate from the nose to the brain on olfactory axons. Their migration is dependent on correct development of the olfactory sensory system (Wray et al., 1989). Developmental pathologies affecting functional GnRH-1 expression, signaling, neuronal development, or migration translate into various forms of hypogonadism, with lack or delay of pubertal onset associated with complex syndromic reproductive dysfunctions (Chan et al., 2009; Trarbach et al., 2009; Wray,

Received Nov. 21, 2010; revised March 17, 2011; accepted March 17, 2011.

Author contributions: P.E.F. and S.W. designed research; P.E.F. and C.T.-B. performed research; V.S.M. and T.W. contributed unpublished reagents/analytic tools; P.E.F., C.T.-B., and S.W. analyzed data; P.E.F., C.T.-B., T.W., and S.W. wrote the paper.

This work was supported by the Intramural Research Program of the National Institutes of Health (NIH), National Institute of Neurological Disorders and Stroke and NIH Grant DE12728 to T.W. We thank Dr. Hui Yang for generation of the Crect mice. Several monoclonal antibodies used in these studies were obtained from the Developmental Studies Hybridoma Bank developed under the National Institute of Child Health and Human Development and maintained by Department of Biology of the University of lowa.

Correspondence should be addressed to Dr. Susan Wray, National Institute of Neurological Disorders and Stroke, National Institutes of Health, Building 35, Room 3A-1012, Bethesda, MD 20892-3703.E-mail: wrays@ninds.nih.gov. DOI:10.1523/JNEUROSCI.6087-10.2011

Copyright $\odot 2011$ the authors $\quad 0270-6474 / 11 / 316915-13 \$ 15.00 / 0$
2010). In humans, the pathology associated with defects in olfactory system development and impaired migration of GnRH-1 neurons is called Kallmann syndrome (Wray, 2010) and is characterized by anosmia (lack of smell) and lack of pubertal onset (Sykiotis et al., 2010). The Kallmann phenotype can be associated with other syndromic diseases such as CHARGE syndrome (Ogata et al., 2006) and can display neural crest (NC)-associated defects involving craniofacial dysmorphisms, cleft palate, dental agenesis, synkinesis, lack of mirror movements, deafness, ocular albinism, cerebellar defects, and dementia (Krams et al., 1997; Molsted et al., 1997; Ueno et al., 2004; Hou, 2005; Zenaty et al., 2006; Bhagavath and Layman, 2007). However, localization and lineage of GnRH-1 progenitors is still unclear. Placodal, nonplacodal ectodermal, and NC origins have all been proposed for these cells (elAmraoui and Dubois, 1993; Whitlock et al., 2003; Merlo et al., 2007; Metz and Wray, 2010).

The NC is an embryonic cell type unique to vertebrates that arises at the junction between the neural tube and epidermis. At early developmental stages, pluripotent NC cells migrate throughout the organism and give rise to many derivates including neurons and glia of the peripheral nervous system, bone and cartilage of the skull, and melanocytes (Bronner-Fraser, 1995). To explore NC and ectodermal contribution to the development of the olfactory and GnRH-1 systems, genetic Cre-lox lineage tracing of NC derivatives and ectodermal derivatives was performed using the NC-specific Wnt1Cre mouse line and an ectodermal-specific Crect mouse line. By using two complementary mouse models, we demonstrate the NC origin of the OECs and an NC contribution to subsets of GnRH-1 neurons and cells of the olfactory epithelium (OE) and vomeronasal organ (VNO). These findings offer a new scenario for the development of GnRH-1 neurons and the olfactory system, and provide a link between NC defects and anosmia associated with hypogonadic syndromes. 


\section{Materials and Methods}

Animals

All procedures were approved by the National Institute of Neurological Disorders and Stroke Animal Care and Use Committee and performed in accordance with National Institutes of Health (NIH) guidelines.

In vivo. Transgenic mice expressing Cre recombinase under the control of either the Wnt1 promoter/enhancer (Danielian et al., 1998) or an AP- $2 \alpha$ ectodermal-specific cis-regulatory element (Crect) $(\mathrm{H}$. Yang and T. Williams, unpublished observation) (Harlow et al., 2011) were mated with R26LacZ (Soriano, 1999) (termed RLacZ) or Gt (Rosa)26Sor ${ }^{\text {Tm(EYFP)Cos }}$ (termed RYFP) reporter mice (Srinivas et al., 2001) to obtain Wnt1Crel RLacZ, Wnt1Cre/RYFP, and Crect/RLacZ or Crect/RYFP mice. RLacZ and RYFP were obtained from Drs. L. Belluscio (National Institute of Neurological Disorders and Stroke, Bethesda, MD) and M. Kelly (National Institute on Deafness and Other Communication Disorders, Bethesda, $\mathrm{MD})$, respectively. For time mating experiments, the day of vaginal plug was considered E0.5. For Wnt1Cre/RLacZ and Wnt1Cre/RYFP lines, the following stages (numbers) of mice were examined: E8.5 (5), E9.5 (3), E10.5 (9), E11/E11.5 (17), E12 (2) E14.5 (5), E16.5 (3), E19.5 (1), postnatal day 0 (P0)-P6 (5), adult (2). For the Crect/RLacZ line, four mice at E16.5 and four Crect/RYFP mice at P0-P5 were examined. For all analyzed lines, no male/female distinction was made for the observations.

Animals were euthanized in a $\mathrm{CO}_{2}$ chamber. Adult mice were perfused with cold PBS followed by $4 \%$ paraformaldehyde (PFA) in PBS. Brains were removed and postfixed by immersion in 4\% PFA in PBS for $1 \mathrm{~h}$. Embryos were removed from the uterus and fixed by immersion in $4 \%$ PFA (30 min). Early postnatal mice were decapitated and the heads fixed in $4 \%$ PFA (30 min). Specimens were cryoprotected in 30\% sucrose/PBS at $4^{\circ} \mathrm{C}$ overnight, embedded in Tissue-Tek OCT compound (Sakura Finetek), frozen in dry ice, and stored at $-80^{\circ} \mathrm{C}$ until sectioning. Frozen samples were cut in serial sections $(12-16 \mu \mathrm{m})$ using a Leica CM $3050 \mathrm{~S}$ cyrostat (Leica Biosystems) and maintained at $-80^{\circ} \mathrm{C}$ until processing. Two serial series were generated for E8.5, E9.5, E10.5, and E11.5; two series for E14.5 embryos; five series for E15.5 embryos; and seven series for E16.5 and postnatal animals.

In vitro. Nasal explants devoid of brain tissue were cultured as described previously (Fueshko and Wray, 1994). Briefly, embryos were obtained from timed pregnant Wnt1Cre/RYFP mice. Bilateral olfactory pits were dissected, trimmed, and adhered onto coverslips by a plasma (Cocalico Biologicals)/thrombin (Sigma-Aldrich) clot. Explants were maintained in defined serum-free medium (SFM) (Fueshko and Wray, 1994 ) at $37^{\circ} \mathrm{C}$ with $5 \% \mathrm{CO}_{2}$. On culture day 3 , fresh media containing 5-fluoro-2' -deoxyuridine $\left(8 \times 10^{-5} \mathrm{M}\right.$; Sigma $)$ was given to inhibit proliferation of dividing olfactory neurons and nonneuronal explant tissue. On culture day 6 , the media was changed with fresh SFM. On day 7 , explants were fixed in $4 \%$ formaldehyde/PBS and immunostained.

\section{Immunolabeling}

Primary antibodies. All antibodies used were polyclonal unless otherwise indicated: GnRH-1 (SW-1, 1:3000) (Wray et al., 1988), rabbit (Rb) antiperipherin (peripheral intermediate filament marker; 1:2000; Millipore Bioscience Research Reagents), mouse monoclonal biotinylated antiHuC-D (1:100; Invitrogen), goat anti-Sox2 (1:800; Santa Cruz Biotechnology), Rb anti-Sox2 (1:500; Millipore Bioscience Research Reagents), mouse monoclonal anti-Tubulin III (Tuj-1, 1:700; Sigma-Aldrich), goat anti-olfactory marker protein (OMP) (1:5000) (Keller and Margolis, 1975), chicken anti-green fluorescent protein (GFP)/yellow fluorescent protein (YFP) (1:1000; Abcam), Rb anti-GFP/YFP (1:20,000; Invitrogen; used in double-labeling experiments involving primary antibodies made in goat), Rb anti-PAX6 (1:400; Millipore Bioscience Research Reagents), mouse monoclonal anti-PAX7 [supernatant 1:3; Developmental Studies Hybridoma Bank (DSHB), University of Iowa], mouse monoclonal antiAp-2 $\alpha$ (3B5 supernatant 1:3; DSHB), Rb anti-PAX7 (1:450; Santa Cruz Biotechnology), goat anti-Sox10 (1:400, Santa Cruz Biotechnology), mouse monoclonal anti-Sus4 (1:200; gift of J. Schwob, Tufts University School of Medicine, Boston, MA), Rb anti-GFAP (1:5; Millipore Bioscience Research Reagents), Rb anti-p75 (1:5000; Millipore Bioscience Research Reagents), Rb anti-brain lipid binding protein (BLBP) (1:1000; Millipore Bioscience Research Reagents), Rb anti p-Histone-3 (1:300;
Millipore), and mouse monoclonal anti-Cre (1:200; Sigma). For the antigens Sox2, PAX6, PAX7, p-Histone-3, and AP- $2 \alpha$, microwave antigen retrieval treatment in citrate buffer was performed before immunostaining (Forni et al., 2006); for Sox10, a 5-10 min 100\% methanol pretreatment was performed.

Chromogen-based reactions. Sections were washed in PBS, blocked in $10 \%$ normal horse or goat serum (depending on experimental needs) and $0.3 \%$ Triton X-100 and then washed in PBS. After incubations with primary antibody ( $1 \mathrm{~h}$ at room temperature or $4^{\circ} \mathrm{C}$ overnight), the following biotinylated secondary antibodies were used: goat anti-rabbit (GAR-Bt; Vector Laboratories), goat anti-mouse (GAM-Bt; Millipore Bioscience Research Reagents), and donkey anti-chicken (DAC-Bt; Jackson ImmunoResearch). After PBS washes, the tissues were processed using a standard avidin-biotin-horseradish peroxidase $/ 3^{\prime}$, standard 3-diaminobenzidine (DAB) protocol or nickel-intensified DAB (Kramer et al., 2000).

Immunofluorescence. Depending on the primary antibody used, sections or explants were incubated for $1 \mathrm{~h}$ with the following secondary antibodies: goat anti-rabbit (GAR) 488 (1:1000), GAR 555 (1:1000), donkey anti-rabbit (DAR) 488 (1:1000), donkey anti-goat 568 (1:1000), goat anti-mouse 488 (1:1000), goat anti-mouse 555 (1:1000), avidin cy3 (1:1000), goat antichicken 488 (1:1000) (all from Invitrogen), and daylight fragment antigenbinding DAR 549 and 488 (1:1000; Jackson ImmunoResearch). Sections were counterstained with 4',6-diamidino-2-phenylindole (DAPI; 1:3000/ PBS; Sigma-Aldrich), rinsed in deionized water, and coverslipped with Fluoro Gel (Electron Microscopy Service). Confocal pictures were taken on a spinning disk confocal system (CSU10; Yocogawa) mounted on an Eclipse TSE200 microscope (Nikon) using an EMCCD ImageM digital camera (Hamamatzu) with I-Vision software (Biovision). Nonconfocal fluorescent pictures were taken on a Nikon Eclipse E800 with a Retiga SRV camera using QCapture software (QImaging). Images were further analyzed using NIH ImageJ software (W. Rasband, NIH, Bethesda, MD).

Cre expression. Serial sections from Wnt1Cre/RYFP embryos immunostained for Cre and YFP as described above were analyzed at E8.5 $(N=5$; two or three sections per animal), E9.5 $(N=2$; five sections per animal), E10.5 $(N=3$; seven sections per animal $)$, and E11.5 $(N=2$; seven sections per animal).

\section{$X$-Gal staining}

For X-Gal staining, sections were rinsed in PBS (10 min) and then incubated overnight at $37^{\circ} \mathrm{C}$ in a solution of $5 \mathrm{~mm}$ potassium ferrocyanide, $5 \mathrm{~mm}$ potassium ferricyanide, $2 \mathrm{~mm} \mathrm{MgCl}_{2}, 0.1 \%$ Tween 20, 0.1\% 5-bromo-4chloro-3-indolyl- $\beta$-D-galactoside/ $N, N$-dimethylformamide (Prunotto et al., 2004). Sections from $R L a c Z$ animals negative for Cre were used as negative controls. After enzymatic reaction slides were either counterstained with Eosin B (Sigma-Aldrich) following the standard procedure and coverslipped or washed and immunostained as described above.

\section{Cell counts}

Labeled GnRH-1 cells in vivo. The number of GnRH-1+/ $\beta \mathrm{Gal}+$ cells were counted at $20 \times$ on a brightfield microscope after X-Gal enzymatic reaction and GnRH-1 immunolabeling. Counts were performed on at least two series per animal. The number of GnRH- $1+/ \beta \mathrm{Gal}+$ cells and the number of total GnRH-1 cells were calculated for each animal as the average of the counted cells per series multiplied by the number of series cut per animal. At least three animals per group were counted, and the mean number of GnRH-1+/ $\beta \mathrm{Gal}+$ cells and the total number of GnRH-1 cells were obtained. The data are presented as the percentage of $\mathrm{GnRH}-1+/ \beta \mathrm{Gal}+$ cells.

YFP/Hu cells. Wht1Cre/RYFP E10.5 embryonic sections were immunolabeled for $\mathrm{Hu}$ and YFP; $\mathrm{Hu}+/ \mathrm{YFP}+$ cells and total YFP + cells in the olfactory pit were counted on four coronal sections in one series for each embryo $(N=$ 3). Mean values were calculated for each animal. The data are presented as the percentage of $\mathrm{Hu}+/ \mathrm{YFP}+$ cells over total YFP cells counted.

Asymmetry of recombinant cells. Quantification of cells positive for the Wntl lineage on the left versus the right side was performed on coronal sections containing (1) the olfactory pit region at E10.5E11.5 $(N=3 ; 6-12$ sections per animal $),(2)$ the OE at E16.5-P0 $(N=$ $5 ; 6-27$ sections per animal), and (3) the VNO at E16.5-P6 $(N=4$; $4-36$ sections per animal). Sections were examined at $25 \times$, and cells 

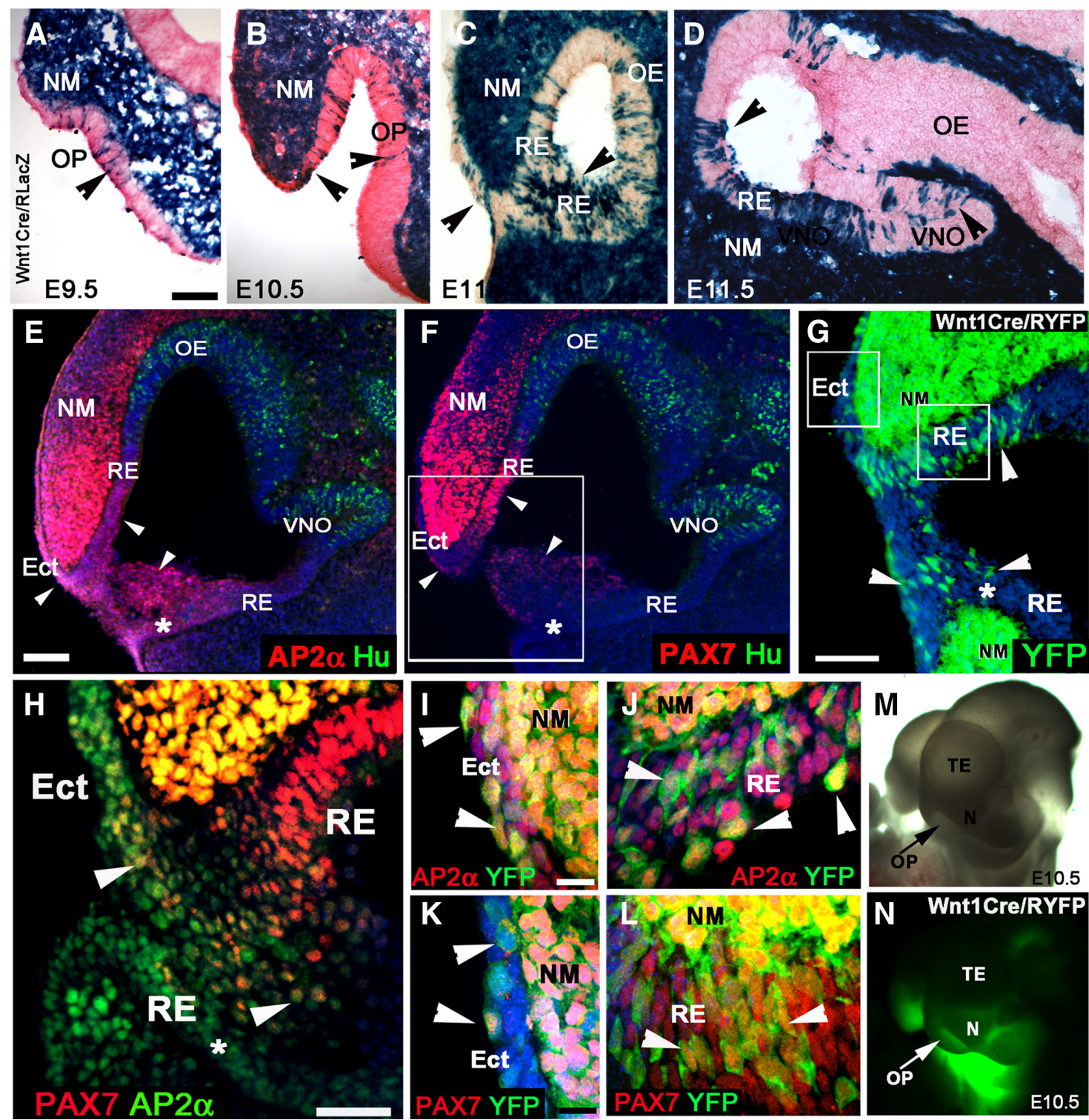

Figure 1. Wnt1Crelineage tracing reveals NC cells in the developing nasal placode. A-D,X-Gal reaction on sections of Wnt1Cre/RLacZE9.5-E11.5 showed $\beta$-gal expression (blue) throughout the nasal ectomesenchyma (NM) and in some cells in the olfactory pit (OP; arrowheads). From E11 to E11.5 (C, D), $\beta$-gal + cells were detected spanning between the dorsal and ventral rim of the invaginating pit (C, between black arrowheads) at the level of the putative RE, VNO, and part of the developing $0 E$. E-G, Near the rim of the invaginating pit, AP-2 $\alpha+$ and PAX7 + cells overlap in

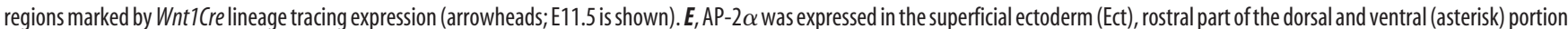
of the RE. F, PAX7 + cells were found in the NM, at the dorsal rim of the invaginating pit, and in the rostral part of the dorsal portion of the RE, whereas the majority of the cells in the ventral RE (asterisk) where negative for PAX7 expression. No immunodetectable PAX7 was found in the 0E and VN0, demarcated by the neuronal marker Hu. G, Region from a Wnt 1 Cre/RYFP embryonic section, comparable to area boxed in $F$, immunostained against YFP. Recombination was found in some cells along the Ect, at the dorsal rim of the $0 P$, along the RE, and spanning between dorsal and ventral (asterisk) rim of the RE. $\boldsymbol{H}$, Double immunostaining for PAX7 and AP-2 $\alpha+$ identified PAX7 expression in subsets of AP- $2 \alpha+$ cells (arrowheads; E11.5 is shown). Double-labeled cells were detected along the superficial Ect, lining the invaginating pit, and spanning from the dorsal to the ventral (asterisk) RE. $I-L$, Colocalization of AP- $2 \alpha+/$ YFP $(I, J)$ and PAX7+/YFP $(K, L)$ in sections of Wnt 1 Cre/RYFP (E11.5 is shown). The areas of $I$ and $\boldsymbol{K}$ are shown in the Ect box in $\boldsymbol{G}$. The areas of $J$ and $\boldsymbol{L}$ are shown in the RE box in $\mathbf{G}$. AP- $2 \alpha+/ \mathrm{YFP}+$ and PAX7 $+/ \mathrm{YFP}+$ cells were detected along the dorsal superficial Ect lining the pit $(\boldsymbol{I}, \boldsymbol{K})$ and in the $\mathrm{RE}(\boldsymbol{J}, \boldsymbol{L}) . \boldsymbol{M}, \boldsymbol{N}$, Images of an E10.5 Wnt 1 Cre/RYFP embryo head photographed in normal $(\boldsymbol{M})$ and fluorescent $(\boldsymbol{N})$ light illustrate recombination in the facial mesenchyma surrounding the invaginating OP (arrow). TE, Telencephalon. Scale bars: $\boldsymbol{A}$ (for $\boldsymbol{A}-\boldsymbol{D}), \boldsymbol{E}$ (for $\boldsymbol{E}, \boldsymbol{F}), \boldsymbol{G}, \boldsymbol{H}, 50 \mu \mathrm{m} ; \boldsymbol{I}($ for $\boldsymbol{I}, \boldsymbol{J}), \boldsymbol{K}$ (for $\boldsymbol{K}, \boldsymbol{L}), 12 \mu \mathrm{m}$.

within the region of interest were counted. The percentage of cells on left versus the right were calculated for each animal based on total number of labeled cells in the region, and a mean percentage was obtained for each group.

Comparison of Wnt1Cre and Crect recombination. To compare recombination numbers between Wnt1Cre and Crect animals, cells either positive or negative (respectively) for Cre recombination were counted in five coronal sections per animal, stained for YFP, $\mathrm{Hu}$, and DAPI from P0-P6 mice $(N=3$ per group; $40 \times)$. Because of the consistent lower recombination observed on the left side of Wnt1Cre animals, all counts were performed on the right side of the VNO. To control for differences in cell density (attributable to age and/or strain), cell counts based on DAPI nuclear staining were performed on two sections per animal from a P5 Crect/RYFP mouse, a P6 Wnt1Cre/RYFP mouse, and P0 Wnt1Cre/ RYFP mouse. DAPI-positive nuclei were counted in two regions per section $\left(50 \mu \mathrm{m}^{2}\right.$ each; $\left.20 \times\right)$ of the sensory VNO. Cell density was then used to calculate the total number of cells per area counted for each animal. Positive (Wnt1Cre) and negative (Crect) cells are reported as the number of cells counted per $3225 \mathrm{VNO}$ cells (smallest area examined of the six mice).

GnRH-1 and OEC quantification in Wnt1Cre/RYFP nasal explants. Counts were performed on $40 \times$ or $60 \times$ confocal digital images obtained 

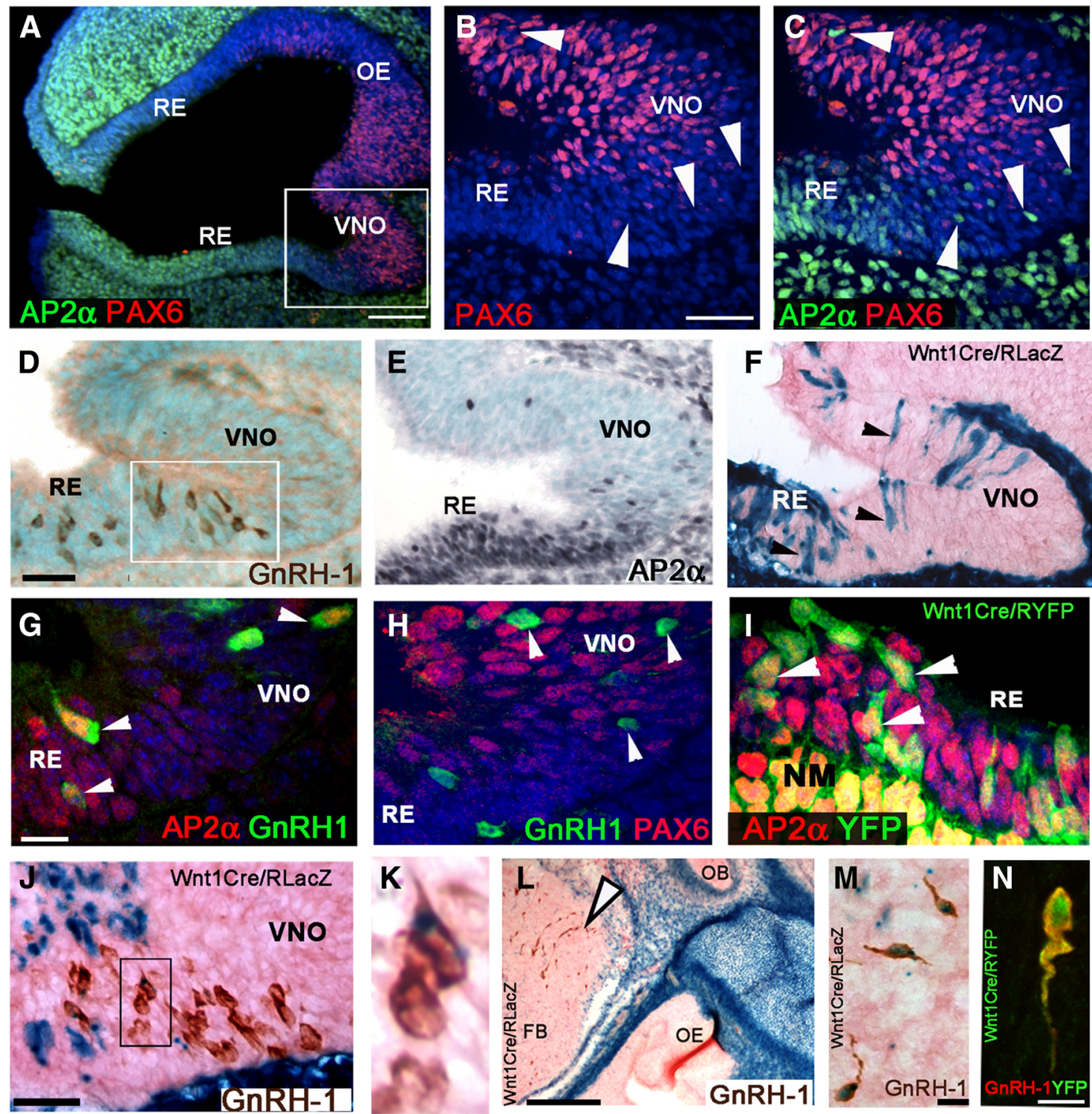

Figure 2. NC cells contribute to the GnRH-1 neuronal population. $\boldsymbol{A}-\boldsymbol{C}, \mathrm{AP}-2 \alpha+$ and PAX6 do not colocalize in cells in the developing VNO (box). AP-2 $\alpha+$ cells are present in the putative RE ( $\boldsymbol{A}$, C), whereas PAX6 expression appears in the OE and VNO (A,B).D, The first GnRH-1+ neurons (brown) detected in the VN0 are located at the border between the RE and developing VNO. E, AP-2 $\alpha+$ is expressed throughout the RE, with AP- $2 \alpha+$ cells in the same area where GnRH-1 neurons form, as well as sporadically in the VNO.F, Wnt 1 Cre/RLacZ. $\beta$-gal + cells within the RE and ventral VNO are in the same area where GnRH-1 neurons form (compare $\boldsymbol{D}, \boldsymbol{F}$ ) and show a similar distribution to that observed with AP-2 $\alpha+$ (compare, $\boldsymbol{E}, \boldsymbol{F}$ ). $\boldsymbol{G}, \boldsymbol{H}$, At the border between RE and VNO (area shown in box in $\boldsymbol{D})$, GnRH-1 neurons expressing AP-2 $\alpha$ (G, arrowheads) were detected but GnRH-1 neurons were negative for PAX6 expression $(\boldsymbol{H})$. $\boldsymbol{I}$, , (ells positive for both Wnt 1 (re tracing (YFP) and AP-2 $\alpha$ were detected along the RE. J-M, X-Gal/GnRH-1 double staining of Wnt1Cre/RLacZ at E11.5 (J, same region as box in $\boldsymbol{D}$ ) and E14.5 (L). J, Within the VN0, a subpopulation of GnRH-1 neurons was positive for $\beta$-gal + expression. $\boldsymbol{K}$, Magnification of box in $J$. L, A subpopulation of GnRH-1 neurons migrating into the forebrain (FB, arrowhead) was positive for Wnt $1 C r e$ tracing. $\boldsymbol{M}$, higher magnification of GnRH-1 neurons positive for Wnt 1 Cre tracing in the forebrain. $\mathbf{N}$, Confocal image of GnRH-1 neuron positive for Wnt 1 Cre tracing in the forebrain. NM, Nasal ectomesenchyma. Scale bars: $\boldsymbol{A}(10 \mu \mathrm{m}) ; \boldsymbol{B}$ (for $\boldsymbol{B}, \boldsymbol{C}), \boldsymbol{D}$ (for $\boldsymbol{D}-\boldsymbol{F}), \boldsymbol{J}, 25 \mu \mathrm{m} ; \boldsymbol{G}$ (for $\mathbf{G}-\boldsymbol{I}$ ), $10 \mu \mathrm{m} ; \boldsymbol{L}, 100 \mu \mathrm{m} ; \boldsymbol{M}, \boldsymbol{N}, 10 \mu \mathrm{m}$.

from Wnt1Cre/RYFP nasal explants immunofluorescently stained for YFP/GnRH-1 $(N=3)$ or YFP/p75 $(N=3)$.

Recombination in Bowman's gland. Cells were analyzed at $40 \times$ on five section per animal (P0-P6; Crect/RYFP, $N=3$; Wnt1Cre/RYFP, $N=3$ ). Bowman's glands were identified by Sox 2 immunostaining (Guo et al., 2010) on YFP/Sox2-immunolabeled sections. The percentage of cells positive for recombination per animal was determined and the mean percentage was calculated per group.

\section{Results}

Fate-mapping identification of neural-crest-derived cells in the olfactory pit

To investigate, whether there is an NC contribution to olfactory pit development and to test the lineage of GnRH-1 neurons and
OECs in mice, genetic cell fate tracing was performed by crossing the NC-specific Wnt1Cre line (Danielian et al., 1998) with Rosa reporter mouse lines (Soriano, 1999; Srinivas et al., 2001). Wnt1 encodes a glycoprotein that is transiently expressed in premigratory NC (Echelard et al., 1994; Nichols and Bruce, 2006). In Wnt1Cre/RLacZ or Wnt1Cre/RYFP double mutants, irreversible expression of the tracer occurs after Cre-mediated recombination. This allows tracing of cells originating from NC after recombination (Nagoshi et al., 2008).

From E9.5 to E10.5, Wnt1Cre recombination was found in the developing facial mesenchyma and in a subset of cells distributed along the invaginating olfactory pit and the ectoderm lining the nasal placode (Fig. $1 A, B, M, N)$. At E11, cells positive for 




Figure 3. Wnt1Cre tracing labeled a subset of sensory neurons, sustentacular cells, and globose/basal cells (GBCs) in the olfactory epithelium and vomeronasal organ. $A$, Coronal section of Wnt1Cre/RLacZ mouse (PN1). Cells positive for $\beta$-gal + activity (blue) were detected in the 0E, RE, and VNO. B-I, Sections from the 0E of Wnt 1Cre/RYFP PN1 mice are shown. Arrows and arrowheads indicated double- and single-labeled cells, respectively. $B$, Cells positive for both Tubulin III (TUJ1) and YFP were found in the 0E. YFP - /TUJ1+ neurons were also found. C, Wnt 1Cre tracing (YFP +) showed subsets OMP + and OMP - olfactory neurons in proximity to each other. D, Sox2 expression in YFP + sustentacular cells (Sus) intermingled with YFP - cells. E, Sustentacular cells Sus4 + /YFP + intermingled with Sus4 + /YFP - cells. F, YFP + /Sox2 + cells in the RE. G, H, GBCs positive for Sox2 and YFP were associated with olfactory neurons (ON) and sustentacular cells (Sus) positive for Wnt 1Cre tracing. I, PAX6 expression was detected in YFP + GBCS. J, Coronal section of Wnt1Cre/RLacZ from a PN1 mouse VNO. $\beta$-gal + cells (blue) in the sensory portion (s) of the VN0 and in the medial nonsensory portion (ns). $\boldsymbol{K}-\boldsymbol{M}$, VNO sections from Wnt1Cre/RYFP PN1 mice. Arrows and arrowheads indicated double- and single-labeled cells, respectively. $\boldsymbol{K}$, YFP + was found in OMP + vomeronasal neurons and in cells negative for this neuronal marker. $L$, Wnt 1Cre recombination in subsets of Sox $2+$ vomeronasal sustentacular cells intermingled with cells negative for the recombination. $\boldsymbol{M}$, Wnt1 Cre tracing was also detected in some ciliated cells in the TUJ1-nonsensory VNO (nsVNO). Scale bars: $\boldsymbol{A}, 200 \mu \mathrm{m} ; \boldsymbol{B}$ (for $\boldsymbol{B}, \boldsymbol{C}), \boldsymbol{D}$ (for $\boldsymbol{D}-\boldsymbol{F}), 25 \mu \mathrm{m} ; \boldsymbol{G}, 10 \mu \mathrm{m} ; \boldsymbol{H}$ (for $\boldsymbol{H}$, I), $10 \mu \mathrm{m} ; \boldsymbol{J}, 100 \mu \mathrm{m} ; \boldsymbol{K}$ (for $\boldsymbol{K}, \boldsymbol{L}), 10 \mu \mathrm{m} ; \boldsymbol{M}, 10 \mu \mathrm{m}$.

Wnt1Cre recombination were detected in the presumptive respiratory epithelium (RE), the presumptive OE (Fig. 1C), and where the dorsal and ventral rims of the invaginating nasal pit fuse (Fig. $1 C$, between black arrows). Wnt1Cre positive cells were also located in the superficial ectoderm, adjacent to the rim of the olfactory pit. These cells were distributed in a stream that often was contiguous with positive cells in the developing RE (Fig. $1 C, G)$. From E11 to E11.5, the number of cells positive for Wnt1Cre-mediated recombination increased in the RE, VNO, and $\mathrm{OE}$ (Fig. 1C,D).

Cells positive for Wnt1Cre tracing express PAX7 and AP-2 $\alpha$ AP- $2 \alpha$ and PAX7 are transcription factors expressed by NC and are required for craniofacial patterning (Mansouri et al., 1996; Brewer et al., 2004). Notably, AP- $2 \alpha$ is expressed by epithelial cells able to produce keratin and is expressed in the developing RE (Leask et al., 1991; Kramer et al., 2000b). However, both AP- $2 \alpha$ and PAX7 can also be expressed by embry- onic ectoderm (Leask et al., 1991; Lacosta et al., 2005; Basch et al., 2006).

At E11.5, immunolabeling for AP- $2 \alpha$ marked the ectoderm, craniofacial mesenchyma, NC-derived nasal ectomesenchyma (LaMantia et al., 2000), and the majority of ectodermal cells along the putative RE (Fig. $1 E$ ). Immunostaining for PAX7 (Fig. $1 F$ ) also showed expression in cells located in the NC-derived nasal ectomesenchyma as well as in cells at the rim of the invaginating nasal pit and along the putative RE, the same areas where cells positive for AP-2 $\alpha$ (Fig. $1 E$ ) and Wnt1Cre fate mapping were identified (Fig. $1 C, G$ ). No PAX7 immunoreactivity was detected in the $\mathrm{OE}$ or $\mathrm{VNO}$, delineated by staining for the early pan neuronal marker HuC/D (Fig. $1 F$ ) (Forni et al., 2011). Double immunostaining for PAX7 and AP- $2 \alpha$ revealed coexpression in a subset of AP- $2 \alpha$ positive cells, distributed along the ectoderm lining the nasal cavity into the RE (Fig. $1 H$ ).

To determine whether the cells positive for NC fate mapping also expressed AP- $2 \alpha$ and PAX7, immunostaining on E11.5 sections 
of Wnt1Cre/RYFP mice was performed. Cells positive for Wnt1Cre-mediated recombination together with AP- $2 \alpha$ (Fig. $1 I, J)$ and PAX7 $(K, L)$ were found along the superficial ectoderm lining the pit $(I, K)$, in the dorsal rim of the nasal pit $(J, L)$, and distributed along the ventral portion of the putative RE (data not shown). These experiments document the expression of two commonly used NC markers in cells positive for Wnt 1 Cre fate tracing in the developing nasal placode.

\section{A subpopulation of GnRH-1 neurons is positive for $\mathrm{NC}$ tracing}

PAX6 is a transcription factor fundamental for development of placodal structures and GnRH-1 neurons (Dellovade et al., 1998). Expression studies indicate that Pax6 is expressed in the nasal ectoderm (Purcell et al., 2005; Bhattacharyya and Bronner-Fraser, 2008). Immunolabeling for AP-2 $\alpha$ and PAX6 at E11.5 revealed AP-2 $\alpha$ expression in PAX6-negative areas of the developing $\mathrm{RE}$ and PAX6 expression in AP- $2 \alpha$-negative areas of the developing $\mathrm{OE}$ (Fig. $2 \mathrm{~A}$ ). However, within the developing VNO, AP- $2 \alpha$-positive cells were intermingled with PAX6-positive cells, but coexpression was not detected. (Fig. 2B,C). These data suggest that AP- $2 \alpha$ and PAX6 define distinct progenitor cells mixed within the developing nasal placode.

At E11.5, the first GnRH-1-expressing cells can be immunodetected in the ventromedial portion of the developing VNO, an area where $\mathrm{AP}-2 \alpha$ and $\mathrm{Wnt} 1 \mathrm{Cre}$ recombination is detected (Fig. $2 D-F$ ). Double labeling for AP-2 $\alpha$ and GnRH-1 highlighted AP- $2 \alpha$ expression in early GnRH-1 neurons in both the putative RE and in the ventral part of the VNO (Fig. 2G). Immunostaining for PAX6 and GnRH-1 showed GnRH-1 neurons did not express PAX6 (Fig. $2 H$ ). These data suggest an independent lineage for GnRH-1 neurons and VNO sensory neurons (pheromone receptors). Cells positive for AP- $2 \alpha$ and Wnt1Cre recombination were also detected at E11.5 in the putative RE (Fig. 2I) and VNO (data not shown). GnRH-1 immunostaining on E11.5 sections of Wnt1Cre/RLacZ or Wnt1Cre/RYFP mice highlighted Wnt1Cre recombination in some GnRH-1 neurons in both nasal (Fig. 2J,K) and brain (Fig. $2 L-N)$ regions. Cell counts on Wnt1Cre/RLacZ mice sections from E16.5 to P0, time points at which GnRH-1 neuronal migration to the brain has been completed (Forni et al., 2011), showed Wnt1Cre-mediated recombination in $37 \pm 9 \%$ of the total GnRH-1 neuronal population $(N=6)$.

\section{Wnt1Cre lineage in olfactory tissues}

During early development of the olfactory system, expression of both AP- $2 \alpha$ and PAX7 was found in cells positive for Wnt1Cre recombination. Immunolabeling sections of E10.5 Wnt1Cre/ RYFP embryos with $\mathrm{HuC} / \mathrm{D}$ revealed that a small percentage of cells positive for recombination in the developing pit were newly
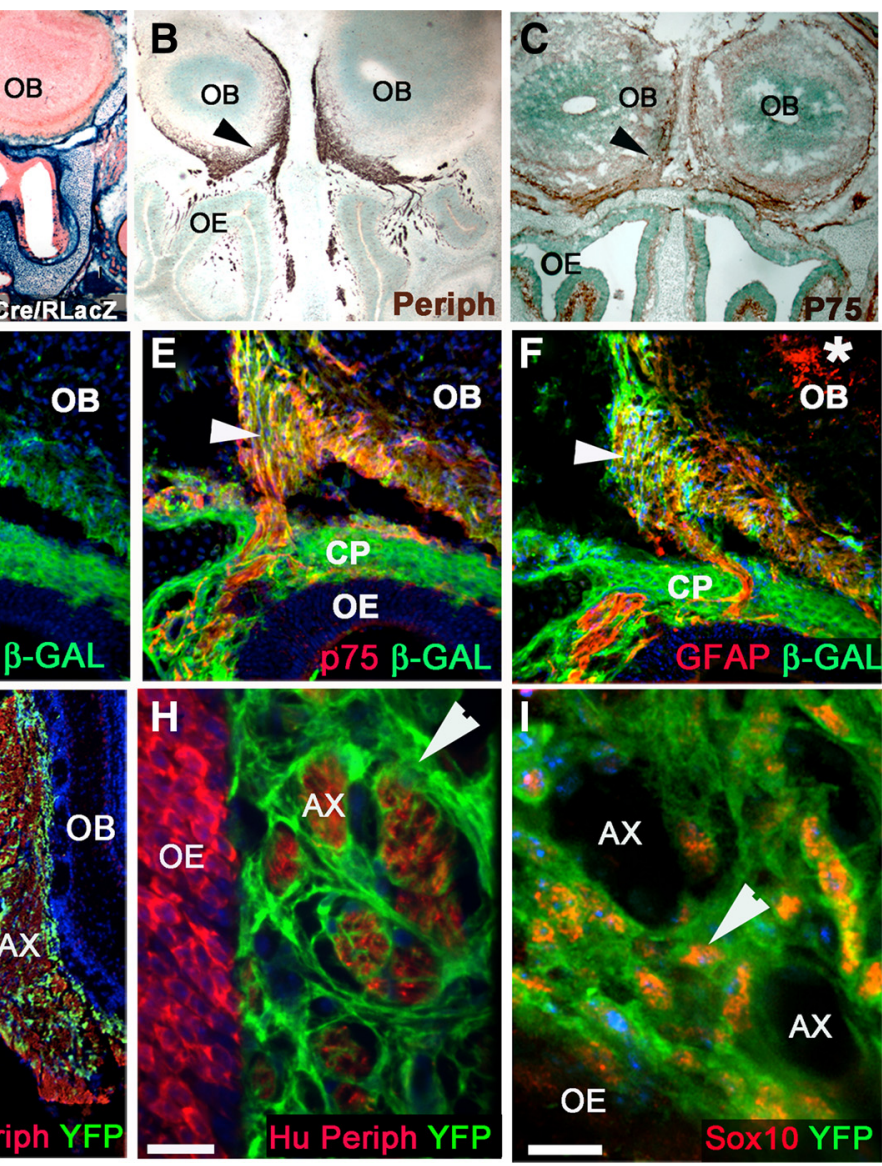

Figure 4. Olfactory ensheathing cells arise from NC cells. $\boldsymbol{A}, \boldsymbol{D}-\boldsymbol{I}$, Sections from Wnt1Cre/RLacZ PN1 mice. $\boldsymbol{A}, \beta$-gal + cells projecting to the $0 B$. C, Immunostaining for 75 labels $0 \mathrm{ECS}$ (arrowhead) surrounding the $0 \mathrm{~B} . \boldsymbol{D}, \beta$-gal expression around the $0 \mathrm{~B}$. a-gal colocalization. $\boldsymbol{F}$, GFAP and $\beta$-gal colocalization in OECS. Glia in the OB were negative for $\beta$-gal (asterisk). surrounding an olfactory axon bundle (AX) negative for both Sox 10 and YFP. (P, Cribriform plate. Scale bars: $\boldsymbol{A}$ (for $\boldsymbol{A}-\boldsymbol{C}$ ), $250 \mu \mathrm{m}$; D (for $\boldsymbol{D}-\boldsymbol{F}$ ), $100 \mu \mathrm{m} ; \boldsymbol{G}, 100 \mu \mathrm{m} ; \boldsymbol{H}, 25 \mu \mathrm{m} ; \boldsymbol{I}, 10 \mu \mathrm{m}$.

formed neurons $(4 \% ; N=4)$. Later stages were examined to understand the final fate of the identified precursors.

Wnt1Cre recombination was found in cells in OE, RE, and VNO (Fig. 3A). In all analyzed animals, higher penetrance of recombination was noticed in the right OE and VNO. Quantification of cells positive for the recombination was performed at E10.5-E11.5 in the olfactory pit and at E16.5-P6 in the OE and VNO on both sides. Although the total number of labeled cells varied, the number of recombined cells was always greater on the right side of the animal independent of age. In fact, all regions examined had $\sim 65 \%$ of labeled cells on the right side and $\sim 35 \%$ on the left (E10.5-E11.5, $N=3$, olfactory pit, $63 \pm 7.5 \%$ right; E16.5-P6, $N=3$, OE, $68 \pm 3 \%$ right; VNO, $65 \pm 3.4 \%$ right). These data suggest lateral differences in the levels of Wnt1Cre activation with respect to the timing of migration (Baker et al., 1997) of these NC cells into the placode.

Identification of the cell types that were positive for Wnt1Cre recombination in the $\mathrm{OE}, \mathrm{RE}$, and $\mathrm{VNO}$ was performed on late staged embryos and perinatal and adult animals. The neuronalspecific antigen Tuj-1 labeled neurons positive for Wnt1Cre recombination in the $\mathrm{OE}$ (Fig. $3 B$ ). Cre recombination was also found in cells negative for Tuj-1 in both the OE as well as the RE (Fig. 3B). Immunolabeling with OMP confirmed that subpopu- 

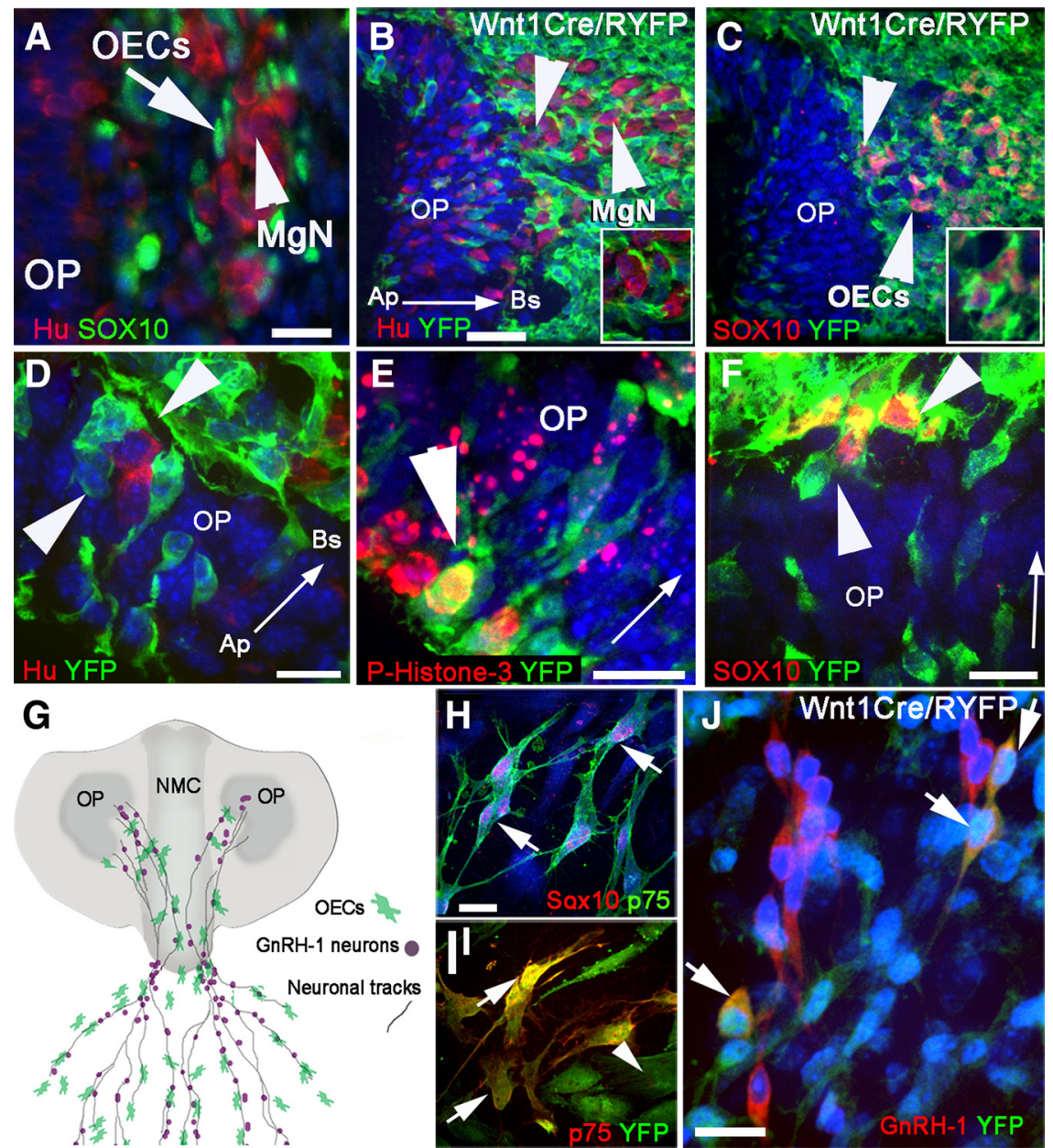

Figure 5. OECs progenitors are detected in the nasal placode. $A-F$, E10.5 Wnt 1 Cre/RYFP cells. $A$, Migratory mass emerging from the $\mathrm{OP}$. $\mathrm{Hu}+$ migratory neurons ( $\mathrm{MgN}$; arrowhead) are surrounded by Sox10+ cells negative for neuronal marker Hu (OECS; arrow). $\boldsymbol{B}$, The majority of $\mathrm{Hu}+$ migratory neurons (emerging from the basal aspect of the olfactory pit; arrowhead) are negative for Wnt1Cre tracing (YFP, see inset). Small arrows (B, D-F) indicate apical (Ap) to basal (Bs) orientation of the placode. $\boldsymbol{C}$ Sox $10+/$ YFP + cells (arrowheads and inset) are detected surrounding the migratory neurons $(\boldsymbol{B})$. $\boldsymbol{D}$, YFP + cells span from the apical to basal aspect of the pit, surrounding Hu + neurons on the basal aspect (arrowheads). $\boldsymbol{E}$, $\mathrm{p}$-Histone-3/YFP double immunostaining showed YFP + mitotic progenitor (arrowhead) at the apical layer of the invaginating pit as well cells having moved toward the basal layer. $\boldsymbol{F}$, Sox 10 is expressed in YFP+ OECs precursors as they exit from the basal portion of the OP. G, Schematic representation of nasal explant at 7DIV with GnRH-1 neurons, ensheathing cells, and olfactory fibers. OP, Olfactory pit; NMC, nasal midline cartilage. $\boldsymbol{H}$, Sox 10 was expressed in p $75+$ cells (arrows; NIH Swiss explant; 7DIV). I, Wnt TCre/RYFP explant. p75 and YFP colocalize in OECS (arrows) but not in nasal fibroblasts (arrowheads). J, Wnt1Cre/RYFP explant. GnRH-1 and YFP colocalize in a subset of GnRH-1 neurons. Scale bars: $\boldsymbol{A}, 10 \mu \mathrm{m} ; \boldsymbol{B}$ (for $\boldsymbol{B}, \boldsymbol{C}), 25 \mu \mathrm{m} ; \boldsymbol{E}, 10 \mu \mathrm{m} ; \boldsymbol{F}, 10 \mu \mathrm{m} ; \boldsymbol{H}$ (for $\boldsymbol{H}, \boldsymbol{I}$ ), $10 \mu \mathrm{m}$.

lations of olfactory neurons arise via the Wnt1Cre lineage (Fig. $3 C)$. Next, the cell lineage of sustentacular cells, which act as support cells within the OE, was examined. Sox 2 is expressed by both sustentacular cells and by globose olfactory stem cells (Guo et al., 2010), whereas SUS4 marks sustentacular cells (Goldstein and Schwob, 1996; Goldstein et al., 1997). Immunolabeling for Sox2 (Fig. 3D) and SUS4 (E) highlighted Wnt1Cre recombination in subpopulations of sustentacular cells. Sox2-expressing cells, positive for Wnt1Cre tracing but negative for SUS4 staining (data not shown) were also detected in the nonneuronal RE (Fig. $3 F)$. A spatial correlation was observed in the distribution of olfactory neurons and sustentacular cells positive for recombination suggestive of a common "clonal" origin of these cells from Wnt1Cre-lineage-derived progenitors (Fig. $3 D, G, H$ ). At postnatal stages, Sox 2 and PAX6 are expressed by Bowman's glands and sustentacular and globose cells (Guo et al., 2010). Staining for PAX6 and Sox 2 confirmed the presence of globose cells positive for Wnt1Cre tracing intermingled with globose cells negative for the recombination in the same areas where olfactory neurons and sustentacular cells positive for Wnt1Cre tracing were found (Fig. 3G-I). No recombination was detected in Bowman's glands. Wnt1Cre cell fate tracing also highlighted the presence of positive cells in the VNO (Fig. 3J). In this region, subpopulations of sensory neurons (OMP positive) positive for Wnt1Cre tracing (Fig. $3 \mathrm{~K}$ ) were found together with Sox2 positive sustentacular cells (Fig. 3L). In the nonsensory epithelium, recombination was occasionally found in nonsensory ciliate cells (Fig. 3M).

Olfactory ensheathing cells are positive for Wnt1Cre tracing

Analyzing Wnt1Cre/RLacZ mice, recombination was noticed around the olfactory bulbs (Fig. $4 A$ ), in an area where olfactory axons (Fig. $4 B$ ), surrounded by ensheathing cells (Fig. 4C), project to the olfactory bulbs. OECs can be identified by GFAP, P75, and BLBP expression (Wewetzer et al., 2002; Murdoch et al., 2010). Immunolabelings for p75 (Fig. 4D,E), GFAP (Fig. $4 F$ ), and BLBP (data not shown) confirmed Wnt1Cre recombination in OECs; no recombination was found in glia within the bulbs (Fig. 4F). Cells positive for Wnt1Cre tracing were found surrounding peripherin positive olfactory axon bundles (Fig. 4G,H) projecting to the bulbs and proximal to the OE (Fig. $4 H)$. Because the OECs were positive for the $\mathrm{NC}$ tracing, we verified whether, as for NC derived Schwann cells of the peripheral system (Joseph et al., 2004), Sox10 was expressed (Finzsch et al., 2010). Sox10 immunostaining showed Sox10 expression in the OECs positive for Wnt1Cre tracing (Fig. 4I).

To address whether the early NC cells detected within the developing placode give rise to OECs, E10.5 embryos were examined. At this stage, a migratory cell mass emerges from the olfactory pit (Miller et al., 2010). HuC/D-positive migratory neurons (Fornaro et al., 2003) were found to be surrounded by nonneuronal Sox10-positive OEC precursors (Fig. 5A). The majority of the migratory neurons were negative for Wnt1Cre tracing (Fig. $5 B$ ), whereas the Sox10-positive cells surrounding the migratory neurons were positive for Wnt1Cre tracing (Fig. 5C). No Sox10positive cells were detected within the olfactory pit at this stage (Fig. 5C). Cells positive for Wnt1Cre recombination were found at the apical side of the invaginating pit and spanning across the epithelium to the basal edge, the majority of which were negative for the neuronal marker $\mathrm{Hu} \mathrm{C} / \mathrm{D}$ (Fig. 5D). Proliferative cells positive for Wnt1Cre recombination were found at the apical level of the invaginating pit, giving rise to daughter cells nearing the basal edge (Fig. $5 E$ ). As cells positive for the recombination $(\mathrm{YFP}+)$ reached the basal edge of the developing placode, Sox10 expression was detected (Fig. 5A,F). These cells surrounded the migratory neuronal mass as it moved toward the forebrain (Fig. 
$5 A-C)$. These data strongly suggest that at early stages NC cells within the placode (positive for Wnt1Cre recombination) give rise to OEC progenitors.

In vitro analysis on embryonic nasal explants (Fig. 5G) (Ichikawa and Osada, 1995; Toba et al., 2008) confirmed Sox10 expression in p75+ OECs (Fig. 5H,I) and recombination in a subpopulation of GnRH-1 neurons (Fig. 5J). Quantification of doublelabeled cells in 7 day in vitro (7DIV) explants revealed a $93 \pm 8 \%$ penetrance of Wnt1Cre recombination in p75+ OECs $(N=3)$ and a $27 \pm 3 \%$ recombination in GnRH-1 neurons $(N=3)$, similar to that observed in vivo.

Ectodermal lineage tracing labels the majority of sensory and GnRH-1 neurons, but not olfactory ensheathing cells

Wnt1Cre tracing analysis, together with the expression of the NC markers AP- $2 \alpha$, PAX7, and Sox10, suggested an NC origin for OECs and a potential common NC origin for subpopulations of GnRH-1 neurons and olfactory/vomeronasal cells. Previous analysis at E13.5 indicated that Wnt1 is not expressed in the developing olfactory system (Rodriguez-Gil and Greer, 2008). To rule out ectopic Cre expression in the developing placode, immunostaining for Cre was performed on embryos at E8.5 $(N=5)$, E9.5 $(N=2), \mathrm{E} 10.5(N=4)$, and E11.5 $(N=2)$. At E8.5, cranial NC cells positive for the recombination were detected invading the interstitial space between the developing brain and the superficial ectoderm (Fig. 6A). Because of the stability of the protein, Cre was still immunodetectable in some cells of the facial mesenchyma (Echelard et al., 1994; Forni et al., 2006) (Fig. 6 B). Notably at this stage, some cells positive for Wnt1 Cre recombination were already detected in association with the superficial ectoderm where no Cre immunoreactivity was found (Fig. $6 \mathrm{~B}$ ). Analysis at E9.5, E10.5 (Fig. 6D, E, G, H), and E11.5 (data not shown) did not detect ectopic Cre expression in the developing placode, where cells positive for the recombination were found. At all analyzed ages, Cre immunoreactivity was found in the dorsal neural tube (Fig. 6C, F, I) and developing hindbrain (data not shown).

To ensure that cells positive for Wnt1Cre lineage were not derived from the ectoderm of the nasal placode, an AP- $2 \alpha$-based Cre recombinase transgene was used that is specifically expressed in the early ectoderm of the head from E8.5 onward. In this animal model (Crect line), recombination occurs in all cranial placodes and ectodermally derived tissues (Harlow et al., 2011). The utility of this transgenic line relies on the observation that discrete enhancer elements within Tcfap $2 a$ drive expression in facial ectoderm and NC-derived mesenchyme, respectively (Zhang and Williams, 2003; Harlow et al., 2011).

Crect-mediated recombination was found in the $\mathrm{OE}$ and in axonal bundles projecting to the olfactory bulbs (Fig. $7 A, C, E, G$ ). No recombination was found in the tissue area juxtaposed to the $\mathrm{OE}$ and surrounding the olfactory axons where the OECs localize
(Fig. 7C, E, G). The Crect/RLacZ recombination pattern appeared complementary to that observed in WntlCre/R animals (Fig. $7 B, D, F, H)$. Indeed, in Crect/RYFP mice, immunofluorescence for $\mathrm{Hu}$ /peripherin and YFP showed ectodermal recombination in the majority of mature and immature olfactory neurons, detectable in both soma ( $\mathrm{Hu}$ ) and axons (peripherin). Recombination was observed in all Bowman's glands (Fig. 7E) (see Materials and Methods) but not in the OECs (Fig. 7, compare E, F). Immunofluorescence for OMP and YFP verified that ectodermal recombination occurred in olfactory neurons but not in OECs (Fig. 7, compare $E, G, F, H)$. These data confirm the NC origin of the OECs indicated by Wnt 1 Cre tracing.

To evaluate the complementary pattern of Crect recombination and Wnt1Cre recombination in more detail, the $\mathrm{OE}$ and VNO were further evaluated (Fig. 8, compare $A, E, B, F$ ). In both the OE (Fig. $8 C, D)$ and $\mathrm{VNO}(G, H)$, small subpopulations of cells negative for Crect mediated recombination were observed with similar distribution to that observed after Wnt1Cre recombination. To compare the relative number of cells negative for Crect to cells positive for Wnt1Cre tracing, samples from the $\mathrm{VNO}$, which is a smaller and well defined area, were counted $(N=3$ mice/line). Wnt1Cre recombination was found in $7.3 \pm$ $0.7 \%$ of cells and $6.4 \pm 1.7 \%$ were found negative for Crect recombination (Fig. $8 \mathrm{~K}$ ) (see Materials and Methods). 



Figure 7. Ectoderm-specific Crect tracing and NC Wnt1Cre tracing showed complementary labeling of nasal structures. $\boldsymbol{A}-\boldsymbol{D}, \mathrm{X}$-Gal-stained coronal sections from an E16.5 Crect/RLaCZ mouse $(\boldsymbol{A}, \boldsymbol{C})$ and Wnt 1 Cre/RLacZ mouse $(\boldsymbol{B}, \boldsymbol{D})$. Olfactory bulb (OB), OE, nasal ectomesenchyma (NM) are indicated as well as olfactory axon bundles projecting to the $O B$ (arrow). $A, C$, Crect recombination was found in the majority of the cells in the $\mathrm{OE}$ and in the olfactory axons (AX) projecting to the $O B$ but not in the area juxtaposed to the basal portion of the $0 E$ where $O E C S$ localize ( $\boldsymbol{C}$; arrowhead). $\boldsymbol{B}, \boldsymbol{D}$, Wnt 1 Cre recombination was found in nasal mesenchyma, in the $O E C$ s around the $O B$ and proximal to the basal $O E(D$; arrowhead), and in a few olfactory neurons in the $\mathrm{OE}$. $E$, Immunocolocalization for $\mathrm{Hu}$ (soma of mature and immature olfactory neurons), peripherin (axons), and YFP in postnatal (rect/RYFP mouse highlights recombination in olfactory neurons in the $0 \mathrm{E}$, Bowman's glands (Bg), and olfactory axons (asterisk), but not in the $0 \mathrm{ECS}$ (arrowheads) surrounding the fibers. $\boldsymbol{F}$, Immunocolocalization for Hu/peripherin and YFP in postnatal Wnt1Cre/RYFP showed complementary pattern to that obtained with Crect/RYFP mice: YFP was found in a few neurons in the OE, in the OECS (arrowhead), but not in Bowman's glands. G, OMP and YFP colocalization on a (rect/RYFP section shows ectodermal recombination limited to olfactory axons (arrowheads) projecting to the bulb. H, OMP and YFP colocalization on a Wnt1Cre/RYFP section shows recombination in the OECS (arrowheads) surrounding the axons projecting to the bulb. Scale bars: $\boldsymbol{A}$ (for $\boldsymbol{A}, \boldsymbol{B}), 200 \mu \mathrm{m} ; \boldsymbol{C}($ for $\boldsymbol{C}, \boldsymbol{D}), 100 \mu \mathrm{m} ; \boldsymbol{E}$ (for $\boldsymbol{E}, \boldsymbol{F})$, $25 \mu \mathrm{m} ; \boldsymbol{G}$ (for $\boldsymbol{G}, \boldsymbol{H}$ ), $10 \mu \mathrm{m}$.
Analysis of Crect recombination in GnRH-1 neurons $(N=3)$ (Fig. $8 I, J)$ also revealed a complementary recombination with $73 \pm 7 \%$ of the GnRH-1 neurons in the brain positive for Crect recombination, which, together with the $37 \pm 9 \%$ positive for Wnt1Cre tracing, accounts for the entire GnRH-1 neuronal population.

\section{Discussion}

The origin of GnRH-1 neurons and OECs has been a matter of debate for several decades. Both cell types are associated with the olfactory/nasal placode (Schwanzel-Fukuda and Pfaff, 1989; Wray et al., 1989; Wewetzer et al., 2002; Barnett, 2004; Murdoch et al., 2010). During early development, the nasal placode and cranial neural crest cells share a common border, originating from ectoderm near the neural plate. Mixing of NC and olfactory placode cells has been suggested (Couly and Le Douarin, 1985; Whitlock, 2004; Schlosser, 2010). Thus, we used both NC and ectodermal-specific Cre-lox fate tracing strategies to determine the origin of nasal placode derivates. Here we show that early multipotent cranial NC cells mingle with ectodermally derived cells in the developing nasal placode where they generate (1) unique cell types such as the OECs and (2) neurons with similar features to those of ectodermal origin (Nagoshi et al., 2008, 2009) including a population of $\mathrm{GnRH}-1$-expressing neurons.

The organization and development of the vertebrate head relies in part on contributions from two ectodermal derivatives, the cranial placodes, and the NC. Previous studies have proven an $\mathrm{NC}$ origin for peripheral glia and an NC contribution to ectodermally derived mesencephalic cranial placodes (D'Amico-Martel and Noden, 1983; Begbie and Graham, 2001; Barlow, 2002; Harlow et al., 2011). The notion of an ectodermal versus NC origin of OECs and Schwann cells has puzzled the scientific community for years (Couly and Le Douarin, 1985; Wewetzer et al., 2002). Indirect evidence has suggested a link between these two cell types based on morphology, molecular markers, and function ( $\mathrm{Su}$ and He, 2010). The OECs, (initially named olfactory Schwann cells), like Schwann cells of the peripheral nervous system, promote axonal regrowth and remyelination in the central and peripheral nervous systems (Boyd et al., 2005). A recent study using Pax7Cre genetic tracing showed recombination in OECs, together with subpopulations of olfactory/vomeronasal neurons and sustentacular cells (Murdoch et al., 2010). These authors suggested an $\mathrm{NC}$ contribution to the development of the olfactory system but could not rule out an ectodermal contribution attributable to normal expression of Pax7 during development (Basch et al., 2006). Our experiments show that OECs are positive for Wnt1Cre tracing and negative for ectodermal-specific Crect tracing, proving an exclusive NC origin of OECs in mammals. These data explain the high level of biological and molecular similarity between OECs and Schwann cells and open a new prospective to understanding the interplay between ectoderm and NC (Begbie and Graham, 2001; Barlow, 2002; Creuzet et al., 2004; Zhu et al., 2010; Harlow et al., 2011) in normal and pathological development of the olfactory system.

Since submission of this manuscript, evidence for an NC origin of OECs has been published using neural crest and ectodermal grafts in chicken and Wnt1Cre tracing in mouse (Barraud et al., 2010). As in our study, Barraud et al. (2010) observed Wnt1Cre recombination in OECs and identified Sox10 as a marker of OECs. However, in contrast to results reported for Wnt1Cre recombination in mouse by Barraud et al. (2010), we observed cells positive for Wnt1Cre fate mapping in the nasal placode starting from early stages. At E10.5, maturing Sox10- 



\begin{tabular}{c|c|c|}
$\mathbf{K}$ & \multicolumn{3}{|c|}{ Percentage of positive cells } \\
\hline \hline & Crect & Wnt1Cre \\
\hline OECs & 0 & $93 \pm 8$ \\
\hline $\mathrm{Bg}$ & 100 & 0 \\
\hline $\mathrm{VNO}$ & $94 \pm 2$ & $7.3 \pm 1$ \\
\hline GnRH-1 & $73 \pm 7$ & $37 \pm 9$ \\
\hline $\mathrm{OE}$ & $\mathrm{ND}$ & $\mathrm{ND}$ \\
\hline
\end{tabular}

Figure 8. NC and ectodermal cells contribute to olfactory and GnRH-1 neuronal populations. $\boldsymbol{A}-\boldsymbol{H}$, Staining patterns were examined in the $0 \mathrm{E}(\boldsymbol{A}-\boldsymbol{D})$ and VNO $(\boldsymbol{E}-\boldsymbol{H})$. X-gal enzymatic reaction $(\boldsymbol{A}, \boldsymbol{B}, \boldsymbol{E})$ and YFP immunostaining $(\boldsymbol{C}, \boldsymbol{D}, \boldsymbol{F}-\boldsymbol{H})$ on sections from Crect/R $(\boldsymbol{A}, \boldsymbol{C}-\boldsymbol{E}, \boldsymbol{G}, \boldsymbol{H})$ and $W n t 1 C r e / R(\boldsymbol{B}, \boldsymbol{F})$ mice in the $0 \mathrm{E}$. A nonuniform recombination was found after ectodermal-specific recombination in both the $\mathrm{OE}$ and $\mathrm{VNO}$ (arrowheads). In areas where $\mathrm{OE}$ cells were negative for recombination, lack of recombination was also observed in the globose cells in the basal lamina (smaller arrowheads). Sections from Wnt 1 (re/RLacZ mice showed a pattern of recombination in both the $0 E(B \vee S A)$ and VNO $(\boldsymbol{F} v \boldsymbol{E})$ complementary to that observed after ectodermal fate tracing. $\boldsymbol{C}, \boldsymbol{D}, \boldsymbol{G}, \boldsymbol{H}$, Confocal images of the $\mathrm{OE}(\boldsymbol{C}, \boldsymbol{D})$ and VNO $(\boldsymbol{G}, \boldsymbol{H})$ from Crect/RYFP mice immunostained for YFP and Hu. Subpopulations of neuronal cells (Hu +; arrowheads) and sustentacular cells (Sus; arrow) were negative for the recombination. $\boldsymbol{I}, J$, E16.5 brain sections of (rect/RLacZ $(I)$ and Wnt 1 Cre/RLacZ mice $(J)$ processed for $\beta$-gal expression and immunostained for GnRH-1. GnRH-1 neurons positive for Crect fate tracing and Wnt1Cre tracing are indicated with arrowheads. $\boldsymbol{K}$, Table showing percentage of cells positive for Crect and Wnt 1 Cre tracing as described in Results and Materials and Methods ( $N \leq$ 3). ND, Not determined. Scale bars: $\boldsymbol{A}, \boldsymbol{B}, 50 \mu \mathrm{m} ; \boldsymbol{C}($ for $\boldsymbol{C}, \boldsymbol{D}), 10 \mu \mathrm{m} ; \boldsymbol{E}, \boldsymbol{F}, 50 \mu \mathrm{m} ; \boldsymbol{G}$ (for $\mathbf{G}, \boldsymbol{H}), 10 \mu \mathrm{m} ; \mathrm{I}($ for $\boldsymbol{I}, \boldsymbol{J}), 10 \mu \mathrm{m}$.

positive OEC precursors, positive for Wnt1Cre tracing, formed a continuum with recombination positive cells in the placode. These data indicate that NC cells commingle with placodal ectoderm and that $\mathrm{NC}$-derived progenitors in the placode give rise to cells with different fates including OECs. In addition the expression pattern of Sox10 suggests that it may play a role in OECs maturation, as described for peripheral Schwann cells (Britsch et al., 2001; Finzsch et al., 2010).

Consistent with a neural crest contribution to the olfactory placode, quail chick graft experiments by Couly and Le Douarin (1985) demonstrated that "olfactory Schwann cells" were of placodal origin, but speculated that NC cells may be associated with the neural ridge before transplantation. This possibility, described by Couly and Le Douarin (1985), would also explain the neural crest "contamination" in ectodermal grafts described by Barraud et al. (2010), rather than the nonplacodal origin of the OECs. Other reports support OEC generation from progenitors within the developing olfactory epithelium. Studies on purified cells generated from olfactory epithelium showed clones that generated glial cells with an OEC phenotype (Mumm et al., 1996; Beites et al., 2005). In addition, cultures of OECs have been obtained from dissociated olfactory epithelium from both humans and mice (Chuah and Au, 1991; Au and Roskams, 2002; Zhang et al., 2004; Savchenko et al., 2005; Lima et al., 2006; Ito et al., 2008; Richter et al., 2008).

GnRH-1, vomeronasal, and olfactory neurons have a mixed ectodermal and NC origin

Wnt1Cre recombination was found in $\sim 30 \%$ of the GnRH-1 neurons. This raised the possibility of ectopic Wnt1Cre expression. No Cre expression was found in preplacodal ectoderm or in the developing placode, indicating that Cre was not ectopically expressed. Moreover quantification for Wnt1Cre recombination in GnRH-1 neurons in nasal explants was consistent with that observed in vivo. This negated a potential environmental brain effect on ectopic Wnt1Cre induction (Echelard et al., 1994). Thus, the data point to a mixed origin of these neurons. To verify this, the ectodermal Crect mouse line was used. Crect fate map- 
ping indicates that $\sim 70 \%$ of the GnRH-1 cells are of ectodermal origin. These findings confirm that GnRH-1 neurons are derived from two different lineages, with the majority originating from ectodermal cells and the remaining fraction of $\mathrm{NC}$ origin. These data are consistent with a previous report in which Dlx 5 expression was found in $70 \%$ of migratory $\mathrm{GnRH}-1$ neurons (Merlo et al., 2007). In fact, heterogeneity has been described within GnRH-1 expressing neurons at both the morphological and molecular levels (Wray and Hoffman, 1986; Jasoni et al., 2005; Cottrell et al., 2006; Constantin et al., 2009; Jasoni et al., 2009; Klenke et al., 2010). Moreover, a number of genetic mutations in mouse selectively affect only 30\% of the GnRH-1 neuronal population (Kramer et al., 2000a; Kruger et al., 2004; Givens et al., 2005; Tsai et al., 2005; Cogliati et al., 2007; Giacobini et al., 2007; Miller et al., 2009; Forni et al., 2011). Reassessing some of these studies to determine whether heterogeneity is correlated with GnRH-1 cell lineage may be valuable. The GnRH-1 neurons have been hypothesized to originate from the nasal placode, NC, and RE (Wray et al., 1989; el Amraoui and Dubois, 1993; Dellovade et al., 1998; Whitlock, 2005). This study provides an explanation for these previous contrasting hypotheses. Indeed, in mouse, GnRH-1 neurons originate from both NC and ectodermal progenitors in a region within and at the border of the RE ectoderm and the developing VNO.

A comparison of the results obtained using Wnt1Cre and Crect revealed complementary patterns of staining in the $\mathrm{VNO}$ and olfactory epithelia. Cell counts on VNO samples confirmed that the cells negative for ectodermal recombination were similar in number to those positive for Wnt1Cre tracing. These findings suggest that subpopulations of cells in the olfactory and VNO epithelia might share common NC origin with the OECs, distinct from the surrounding populations of ectodermal origin. As in the GnRH-1 neuronal population, heterogeneity has also been described in olfactory and vomeronasal neurons and globose/basal cells (Fulle et al., 1995; Giannetti and LeJeune, 1996; Goldstein and Schwob, 1996; Juilfs et al., 1997; Gibson and Garbers, 2000; Manglapus et al., 2004; Carson et al., 2006; Murdoch and Roskams, 2007, 2008; Murdoch et al., 2010). Moreover, the presence of NC-derived progenitors in the olfactory epithelium (Fernandes et al., 2004; Biernaskie et al., 2006) is supported by the identification of multipotent cells able to generate neurons, glia, and myofibroblasts (Fernandes et al., 2008).

Unraveling the NC origin of the OECs and NC contribution to the GnRH-1 neurons and vomeronasal/olfactory sensory epithelium is a crucial step for understanding the relation among syndromic developmental defects. Our studies provide an important framework to interpret the genetic causes of sexual pathologies associated with anosmia and NC craniofacial and sensory defects, and indicate that certain conditions impacting olfaction and sexual development, such as Kallmann syndrome, may be in part neurocristopathies. Further characterization of the molecular contribution of the NC to early nasal placode development, as well as the contribution of $\mathrm{NC}$ and ectodermal subpopulations to reproductive and olfactory system function, will provide insight into vertebrate development and physiology.

\section{References}

$\mathrm{Au}$ E, Roskams AJ (2002) Culturing olfactory ensheathing glia from the mouse olfactory epithelium. Methods Mol Biol 198:49-54.

Baker CV, Bronner-Fraser M, Le Douarin NM, Teillet MA (1997) Earlyand late-migrating cranial neural crest cell populations have equivalent developmental potential in vivo. Development 124:3077-3087.

Barlow LA (2002) Cranial nerve development: placodal neurons ride the crest. Curr Biol 12:R171-R173.
Barnett SC (2004) Olfactory ensheathing cells: unique glial cell types? J Neurotrauma 21:375-382.

Barraud P, Seferiadis AA, Tyson LD, Zwart MF, Szabo-Rogers HL, Ruhrberg C, Liu KJ, Baker CV (2010) Neural crest origin of olfactory ensheathing glia. Proc Natl Acad Sci U S A 107:21040-21045.

Basch ML, Bronner-Fraser M, Garcia-Castro MI (2006) Specification of the neural crest occurs during gastrulation and requires Pax7. Nature 441:218-222.

Begbie J, Graham A (2001) Integration between the epibranchial placodes and the hindbrain. Science 294:595-598.

Beites CL, Kawauchi S, Crocker CE, Calof AL (2005) Identification and molecular regulation of neural stem cells in the olfactory epithelium. Exp Cell Res 306:309-316.

Bhagavath B, Layman LC (2007) The genetics of hypogonadotropic hypogonadism. Semin Reprod Med 25:272-286.

Bhattacharyya S, Bronner-Fraser M (2008) Competence, specification and commitment to an olfactory placode fate. Development 135:4165-4177.

Biernaskie JA, McKenzie IA, Toma JG, Miller FD (2006) Isolation of skinderived precursors (SKPs) and differentiation and enrichment of their Schwann cell progeny. Nat Protoc 1:2803-2812.

Boehm U, Zou Z, Buck LB (2005) Feedback loops link odor and pheromone signaling with reproduction. Cell 123:683-695.

Boyd JG, Doucette R, Kawaja MD (2005) Defining the role of olfactory ensheathing cells in facilitating axon remyelination following damage to the spinal cord. FASEB J 19:694-703.

Brewer S, Feng W, Huang J, Sullivan S, Williams T (2004) Wnt1-Cremediated deletion of AP-2alpha causes multiple neural crest-related defects. Dev Biol 267:135-152.

Britsch S, Goerich DE, Riethmacher D, Peirano RI, Rossner M, Nave KA, Birchmeier C, Wegner M (2001) The transcription factor Sox10 is a key regulator of peripheral glial development. Genes Dev 15:66-78.

Bronner-Fraser M (1995) Origins and developmental potential of the neural crest. Exp Cell Res 218:405-417.

Carson C, Murdoch B, Roskams AJ (2006) Notch 2 and Notch 1/3 segregate to neuronal and glial lineages of the developing olfactory epithelium. Dev Dyn 235:1678-1688.

Chan YM, de Guillebon A, Lang-Muritano M, Plummer L, Cerrato F, Tsiaras S, Gaspert A, Lavoie HB, Wu CH, Crowley WF Jr, Amory JK, Pitteloud N, Seminara SB (2009) GNRH1 mutations in patients with idiopathic hypogonadotropic hypogonadism. Proc Natl Acad Sci USA 106:11703-11708.

Chuah MI, Au C (1991) Olfactory Schwann cells are derived from precursor cells in the olfactory epithelium. J Neurosci Res 29:172-180.

Cogliati T, Delgado-Romero P, Norwitz ER, Guduric-Fuchs J, Kaiser UB, Wray S, Kirsch IR (2007) Pubertal impairment in Nhlh2 null mice is associated with hypothalamic and pituitary deficiencies. Mol Endocrinol 21:3013-3027.

Constantin S, Caligioni CS, Stojilkovic S, Wray S (2009) Kisspeptin-10 facilitates a plasma membrane-driven calcium oscillator in gonadotropinreleasing hormone-1 neurons. Endocrinology 150:1400-1412.

Cottrell EC, Campbell RE, Han SK, Herbison AE (2006) Postnatal remodeling of dendritic structure and spine density in gonadotropin-releasing hormone neurons. Endocrinology 147:3652-3661.

Couly GF, Le Douarin NM (1985) Mapping of the early neural primordium in quail-chick chimeras. I. Developmental relationships between placodes, facial ectoderm, and prosencephalon. Dev Biol 110:422-439.

Creuzet S, Schuler B, Couly G, Le Douarin NM (2004) Reciprocal relationships between Fgf8 and neural crest cells in facial and forebrain development. Proc Natl Acad Sci U S A 101:4843-4847.

D’Amico-Martel A, Noden DM (1983) Contributions of placodal and neural crest cells to avian cranial peripheral ganglia. Am J Anat 166:445-468.

Danielian PS, Muccino D, Rowitch DH, Michael SK, McMahon AP (1998) Modification of gene activity in mouse embryos in utero by a tamoxifeninducible form of Cre recombinase. Curr Biol 8:1323-1326.

Dellovade TL, Pfaff DW, Schwanzel-Fukuda M (1998) The gonadotropinreleasing hormone system does not develop in Small-Eye (Sey) mouse phenotype. Brain Res Dev Brain Res 107:233-240.

Echelard Y, Vassileva G, McMahon AP (1994) Cis-acting regulatory sequences governing Wnt-1 expression in the developing mouse CNS. Development 120:2213-2224.

el Amraoui A, Dubois PM (1993) Experimental evidence for an early commitment of gonadotropin-releasing hormone neurons, with special re- 
gard to their origin from the ectoderm of nasal cavity presumptive territory. Neuroendocrinology 57:991-1002.

el Amraoui A, Dubois PM (1993) Experimental evidence for the early commitment of the presumptive adenohypophysis. Neuroendocrinology 58:609-615.

Fernandes KJ, McKenzie IA, Mill P, Smith KM, Akhavan M, Barnabe-Heider F, Biernaskie J, Junek A, Kobayashi NR, Toma JG, Kaplan DR, Labosky PA, Rafuse V, Hui CC, Miller FD (2004) A dermal niche for multipotent adult skin-derived precursor cells. Nat Cell Biol 6:1082-1093.

Fernandes KJ, Toma JG, Miller FD (2008) Multipotent skin-derived precursors: adult neural crest-related precursors with therapeutic potential. Philos Trans R Soc Lond B Biol Sci 363:185-198.

Finzsch M, Schreiner S, Kichko T, Reeh P, Tamm ER, Bosl MR, Meijer D, Wegner M (2010) Sox10 is required for Schwann cell identity and progression beyond the immature Schwann cell stage. J Cell Biol 189:701-712.

Fornaro M, Geuna S, Fasolo A, Giacobini-Robecchi MG (2003) HuC/D confocal imaging points to olfactory migratory cells as the first cell population that expresses a post-mitotic neuronal phenotype in the chick embryo. Neuroscience 122:123-128.

Forni PE, Scuoppo C, Imayoshi I, Taulli R, Dastru W, Sala V, Betz UA, Muzzi P, Martinuzzi D, Vercelli AE, Kageyama R, Ponzetto C (2006) High levels of Cre expression in neuronal progenitors cause defects in brain development leading to microencephaly and hydrocephaly. J Neurosci 26:9593-9602.

Forni PE, Fornaro M, Guenette S, Wray S (2011) A role for FE65 in controlling GnRH-1 neurogenesis. J Neurosci 31:480-491.

Fueshko S, Wray S (1994) LHRH cells migrate on peripherin fibers in embryonic olfactory explant cultures: an in vitro model for neurophilic neuronal migration. Dev Biol 166:331-348.

Fulle HJ, Vassar R, Foster DC, Yang RB, Axel R, Garbers DL (1995) A receptor guanylyl cyclase expressed specifically in olfactory sensory neurons. Proc Natl Acad Sci U S A 92:3571-3575.

Giacobini P, Messina A, Wray S, Giampietro C, Crepaldi T, Carmeliet P, Fasolo A (2007) Hepatocyte growth factor acts as a motogen and guidance signal for gonadotropin hormone-releasing hormone-1 neuronal migration. J Neurosci 27:431-445.

Giannetti N, LeJeune H (1996) Atypical olfactory glomeruli subset of the rat: quantitative study and organization of the peripheral afferents. Chem Senses 21:303-312.

Gibson AD, Garbers DL (2000) Guanylyl cyclases as a family of putative odorant receptors. Annu Rev Neurosci 23:417-439.

Givens ML, Rave-Harel N, Goonewardena VD, Kurotani R, Berdy SE, Swan CH, Rubenstein JL, Robert B, Mellon PL (2005) Developmental regulation of gonadotropin-releasing hormone gene expression by the MSX and DLX homeodomain protein families. J Biol Chem 280:19156-19165.

Goldstein BJ, Schwob JE (1996) Analysis of the globose basal cell compartment in rat olfactory epithelium using GBC-1, a new monoclonal antibody against globose basal cells. J Neurosci 16:4005-4016.

Goldstein BJ, Wolozin BL, Schwob JE (1997) FGF2 suppresses neuronogenesis of a cell line derived from rat olfactory epithelium. J Neurobiol 33:411-428.

Guo Z, Packard A, Krolewski RC, Harris MT, Manglapus GL, Schwob JE (2010) Expression of pax6 and sox2 in adult olfactory epithelium. J Comp Neurol 518:4395-4418.

Harlow DE, Yang H, Williams T, Barlow LA (2011) Epibranchial placodederived neurons produce BDNF required for early sensory neuron development. Dev Dyn 240:309-323.

Hou JW (2005) Detection of gene deletions in children with chondrodysplasia punctata, ichthyosis, Kallmann syndrome, and ocular albinism by FISH studies. Chang Gung Med J 28:643-650.

Ichikawa M, Osada T (1995) Morphology of vomeronasal organ cultures from fetal rat. Anat Embryol (Berl) 191:25-32.

Ito D, Fujita N, Ibanez C, Sasaki N, Franklin RJ, Jeffery ND (2008) Serumfree medium provides a clinically relevant method to increase olfactory ensheathing cell numbers in olfactory mucosa cell culture. Cell Transplant 16:1021-1027.

Jasoni CL, Todman MG, Han SK, Herbison AE (2005) Expression of mRNAs encoding receptors that mediate stress signals in gonadotropin-releasing hormone neurons of the mouse. Neuroendocrinology 82:320-328.

Jasoni CL, Porteous RW, Herbison AE (2009) Anatomical location of mature GnRH neurons corresponds with their birthdate in the developing mouse. Dev Dyn 238:524-531.
Joseph NM, Mukouyama YS, Mosher JT, Jaegle M, Crone SA, Dormand EL, Lee KF, Meijer D, Anderson DJ, Morrison SJ (2004) Neural crest stem cells undergo multilineage differentiation in developing peripheral nerves to generate endoneurial fibroblasts in addition to Schwann cells. Development 131:5599-5612.

Juilfs DM, Fulle HJ, Zhao AZ, Houslay MD, Garbers DL, Beavo JA (1997) A subset of olfactory neurons that selectively express cGMP-stimulated phosphodiesterase (PDE2) and guanylyl cyclase-D define a unique olfactory signal transduction pathway. Proc Natl Acad Sci U S A 94:3388-3395.

Keller A, Margolis FL (1975) Immunological studies of the rat olfactory marker protein. J Neurochem 24:1101-1106.

Klenke U, Constantin S, Wray S (2010) Neuropeptide Y directly inhibits neuronal activity in a subpopulation of gonadotropin-releasing hormone- 1 neurons via Y1 receptors. Endocrinology 151:2736-2746.

Kramer PR, Krishnamurthy R, Mitchell PJ, Wray S (2000a) Transcription factor activator protein-2 is required for continued luteinizing hormonereleasing hormone expression in the forebrain of developing mice. Endocrinology 141:1823-1838.

Kramer PR, Guerrero G, Krishnamurthy R, Mitchell PJ, Wray S (2000b) Ectopic expression of luteinizing hormone-releasing hormone and peripherin in the respiratory epithelium of mice lacking transcription factor AP-2alpha. Mech Dev 94:79-94.

Krams M, Quinton R, Mayston MJ, Harrison LM, Dolan RJ, Bouloux PM, Stephens JA, Frackowiak RS, Passingham RE (1997) Mirror movements in X-linked Kallmann's syndrome. II. A PET study. Brain 120:1217-1228.

Kruger M, Ruschke K, Braun T (2004) NSCL-1 and NSCL-2 synergistically determine the fate of GnRH-1 neurons and control necdin gene expression. EMBO J 23:4353-4364.

Lacosta AM, Muniesa P, Ruberte J, Sarasa M, Dominguez L (2005) Novel expression patterns of Pax $3 / \mathrm{Pax} 7$ in early trunk neural crest and its melanocyte and non-melanocyte lineages in amniote embryos. Pigment Cell Res 18:243-251.

LaMantia AS, Bhasin N, Rhodes K, Heemskerk J (2000) Mesenchymal/epithelial induction mediates olfactory pathway formation. Neuron 28:411-425.

Leask A, Byrne C, Fuchs E (1991) Transcription factor AP2 and its role in epidermal-specific gene expression. Proc Natl Acad Sci USA 88:7948-7952.

Lima C, Pratas-Vital J, Escada P, Hasse-Ferreira A, Capucho C, Peduzzi JD (2006) Olfactory mucosa autografts in human spinal cord injury: a pilot clinical study. J Spinal Cord Med 29:191-203; discussion 204-196.

Manglapus GL, Youngentob SL, Schwob JE (2004) Expression patterns of basic helix-loop-helix transcription factors define subsets of olfactory progenitor cells. J Comp Neurol 479:216-233.

Mansouri A, Stoykova A, Torres M, Gruss P (1996) Dysgenesis of cephalic neural crest derivatives in Pax7-1- mutant mice. Development 122:831-838.

Merlo GR, Mantero S, Zaghetto AA, Peretto P, Paina S, Gozzo M (2007) The role of Dlx homeogenes in early development of the olfactory pathway. J Mol Histol 38:347-358.

Metz H, Wray S (2010) Use of mutant mouse lines to investigate origin of gonadotropin-releasing hormone-1 neurons: lineage independent of the adenohypophysis. Endocrinology 151:766-773.

Miller AM, Treloar HB, Greer CA (2010) Composition of the migratory mass during development of the olfactory nerve. J Comp Neurol 518:4825-4841.

Miller NL, Wevrick R, Mellon PL (2009) Necdin, a Prader-Willi syndrome candidate gene, regulates gonadotropin-releasing hormone neurons during development. Hum Mol Genet 18:248-260.

Molsted K, Kjaer I, Giwercman A, Vesterhauge S, Skakkebaek NE (1997) Craniofacial morphology in patients with Kallmann's syndrome with and without cleft lip and palate. Cleft Palate Craniofac J 34:417-424.

Mumm JS, Shou J, Calof AL (1996) Colony-forming progenitors from mouse olfactory epithelium: evidence for feedback regulation of neuron production. Proc Natl Acad Sci U S A 93:11167-11172.

Murdoch B, Roskams AJ (2007) Olfactory epithelium progenitors: insights from transgenic mice and in vitro biology. J Mol Histol 38:581-599.

Murdoch B, Roskams AJ (2008) A novel embryonic nestin-expressing radial glia-like progenitor gives rise to zonally restricted olfactory and vomeronasal neurons. J Neurosci 28:4271-4282.

Murdoch B, DelConte C, Garcia-Castro MI (2010) Embryonic Pax7- 
expressing progenitors contribute multiple cell types to the postnatal olfactory epithelium. J Neurosci 30:9523-9532.

Nagoshi N, Shibata S, Kubota Y, Nakamura M, Nagai Y, Satoh E, Morikawa S, Okada Y, Mabuchi Y, Katoh H, Okada S, Fukuda K, Suda T, Matsuzaki Y, Toyama Y, Okano H (2008) Ontogeny and multipotency of neural crest-derived stem cells in mouse bone marrow, dorsal root ganglia, and whisker pad. Cell Stem Cell 2:392-403.

Nagoshi N, Shibata S, Nakamura M, Matsuzaki Y, Toyama Y, Okano H (2009) Neural crest-derived stem cells display a wide variety of characteristics. J Cell Biochem 107:1046-1052.

Nichols DH, Bruce LL (2006) Migratory routes and fates of cells transcribing the Wnt-1 gene in the murine hindbrain. Dev Dyn 235:285-300.

Ogata T, Fujiwara I, Ogawa E, Sato N, Udaka T, Kosaki K (2006) Kallmann syndrome phenotype in a female patient with CHARGE syndrome and CHD7 mutation. Endocr J 53:741-743.

Prunotto C, Crepaldi T, Forni PE, Ieraci A, Kelly RG, Tajbakhsh S, Buckingham M, Ponzetto C (2004) Analysis of Mlc-lacZ Met mutants highlights the essential function of Met for migratory precursors of hypaxial muscles and reveals a role for Met in the development of hyoid arch-derived facial muscles. Dev Dyn 231:582-591.

Purcell P, Oliver G, Mardon G, Donner AL, Maas RL (2005) Pax6dependence of Six3, Eya1 and Dach1 expression during lens and nasal placode induction. Gene Expr Patterns 6:110-118.

Richter M, Westendorf K, Roskams AJ (2008) Culturing olfactory ensheathing cells from the mouse olfactory epithelium. Methods Mol Biol 438:95-102.

Rodriguez-Gil DJ, Greer CA (2008) Wnt/Frizzled family members mediate olfactory sensory neuron axon extension. J Comp Neurol 511:301-317.

Savchenko EA, Andreeva NA, Dmitrieva TB, Viktorov IV, Chekhonin VP (2005) Culturing of specialized glial cells (olfactory ensheathing cells) of human olfactory epithelium. Bull Exp Biol Med 139:510-513.

Schlosser G (2010) Making senses development of vertebrate cranial placodes. Int Rev Cell Mol Biol 283:129-234.

Schwanzel-Fukuda M, Pfaff DW (1989) Origin of luteinizing hormonereleasing hormone neurons. Nature 338:161-164.

Soriano P (1999) Generalized lacZ expression with the ROSA26 Cre reporter strain. Nat Genet 21:70-71.

Srinivas S, Watanabe T, Lin CS, William CM, Tanabe Y, Jessell TM, Costantini F (2001) Cre reporter strains produced by targeted insertion of EYFP and ECFP into the ROSA26 locus. BMC Dev Biol 1:4.

Su Z, He C (2010) Olfactory ensheathing cells: Biology in neural development and regeneration. Prog Neurobiol 92:517-532.

Sykiotis GP, Hoang XH, Avbelj M, Hayes FJ, Thambundit A, Dwyer A, Au M, Plummer L, Crowley WF Jr, Pitteloud N (2010) Congenital idiopathic hypogonadotropic hypogonadism: evidence of defects in the hypothalamus, pituitary, and testes. J Clin Endocrinol Metab 95:3019-3027.

Toba Y, Tiong JD, Ma Q, Wray S (2008) CXCR4/SDF-1 system modulates development of GnRH-1 neurons and the olfactory system. Dev Neurobiol 68:487-503.

Trarbach EB, Teles MG, Costa EM, Abreu AP, Garmes HM, Guerra G Jr, Baptista MT, de Castro M, Mendonca BB, Latronico AC (2009) Screening of autosomal gene deletions in patients with hypogonadotropic hypogonadism using multiplex ligation-dependent probe amplification: detection of a hemizygosis for the fibroblast growth factor receptor 1. Clin Endocrinol (Oxf) 72:371-376.

Tsai PS, Moenter SM, Postigo HR, El Majdoubi M, Pak TR, Gill JC, Paruthiyil S, Werner S, Weiner RI (2005) Targeted expression of a dominantnegative fibroblast growth factor (FGF) receptor in gonadotropinreleasing hormone $(\mathrm{GnRH})$ neurons reduces FGF responsiveness and the size of GnRH neuronal population. Mol Endocrinol 19:225-236.

Ueno H, Yamaguchi H, Katakami H, Matsukura S (2004) A case of Kallmann syndrome associated with Dandy-Walker malformation. Exp Clin Endocrinol Diabetes 112:62-67.

Wewetzer K, Verdu E, Angelov DN, Navarro X (2002) Olfactory ensheathing glia and Schwann cells: two of a kind? Cell Tissue Res 309:337-345.

Whitlock KE (2004) A new model for olfactory placode development. Brain Behav Evol 64:126-140.

Whitlock KE (2005) Origin and development of GnRH neurons. Trends Endocrinol Metab 16:145-151.

Whitlock KE, Wolf CD, Boyce ML (2003) Gonadotropin-releasing hormone $(\mathrm{GnRH})$ cells arise from cranial neural crest and adenohypophyseal regions of the neural plate in the zebrafish, Danio rerio. Dev Biol 257:140-152.

Wray S (2010) From nose to brain: development of gonadotrophinreleasing hormone-1 neurones. J Neuroendocrinol 22:743-753.

Wray S, Hoffman G (1986) Postnatal morphological changes in rat LHRH neurons correlated with sexual maturation. Neuroendocrinology 43:93-97.

Wray S, Gahwiler BH, Gainer H (1988) Slice cultures of LHRH neurons in the presence and absence of brainstem and pituitary. Peptides 9:1151-1175.

Wray S, Grant P, Gainer H (1989) Evidence that cells expressing luteinizing hormone-releasing hormone mRNA in the mouse are derived from progenitor cells in the olfactory placode. Proc Natl Acad Sci U S A 86:8132-8136.

Zenaty D, Bretones P, Lambe C, Guemas I, David M, Leger J, de Roux N (2006) Paediatric phenotype of Kallmann syndrome due to mutations of fibroblast growth factor receptor 1 (FGFR1). Mol Cell Endocrinol 254$255: 78-83$.

Zhang J, Williams T (2003) Identification and regulation of tissue-specific cis-acting elements associated with the human AP-2alpha gene. Dev Dyn 228:194-207.

Zhang X, Klueber KM, Guo Z, Lu C, Roisen FJ (2004) Adult human olfactory neural progenitors cultured in defined medium. Exp Neurol 186:112-123.

Zhu Y, Cao L, Su Z, Mu L, Yuan Y, Gao L, Qiu Y, He C (2010) Olfactory ensheathing cells: attractant of neural progenitor migration to olfactory bulb. Glia 58:716-729. 